\title{
$\mathrm{DEA}$ 모형을 이용한 국내 대학의 기술이전 효율성 분석
}

\author{
진경미 ${ }^{1}$, 윤병운 ${ }^{*}$ \\ ${ }^{1}$ 동국대학교 산업시스템공학과
}

\section{A study on the efficiency measurement of University's technology transfer by DEA model}

\author{
Gyungmi Jin $^{1}$ and Byungun Yoon $^{1^{*}}$ \\ ${ }^{1}$ Department of Industrial \& Systems Engineering, Dongguk University
}

\begin{abstract}
요 약 기술 개발에 소요되는 비용이 증가하는 반면 기술 실현화를 통해 개발된 제품이나 서비스의 수명주기는 점 차 짧아지고 있다. 이에 기업은 기술 혁신에 드는 비용을 절감하면서 빠르게 변화하는 시장에 대응하기 위해 개방형 혁신(open innovation)을 적극적으로 실행하고 있다. 그 중, 대학으로부터의 기술이전은 기술혁신의 대표적인 수단 중 의 하나이다. 그러나 대학이 많은 자원을 연구개발에 투자하고 있음에도 투여된 자원이 가져오는 결과는 도외시 되고 있다. 따라서 현 시점에서 대학에서의 기술이전의 성과 및 효율성에 대한 연구가 요구되고 있다. 그러나, 기존 연구는 대부분 기술이전의 성과에 영향을 미치는 요인 분석에 집중되어있기 때문에 본 연구에서는 국내 소재 대학을 대상으 로 대학에서의 기술이전 효율성을 분석하여 효율성 값을 토대로 대학의 유형별 효율성에 차이가 있는지를 검정하였 다. 일반 대학보다 목적성이 있는 특화 대학에서 기술이전 효율성이 높은 것으로 분석되었고, 효율성 프론티어로 선 정된 대학의 수 역시 특화 대학이 많았다. 대학 TLO 육성 지원 사업 참여 여부에 따른 대학에서의 기술이전의 효율 성에는 유의한 차이가 없다는 점을 고려할 때, 국내에서 대학 TLO 육성 지원 사업이 성과를 내기 위해서는 시간이나 노력이 더욱 요구될 것이다. 본 연구의 대학별 효율성 분석은 향후 국내 및 국외 효율성 비교 연구와 대학의 기술이 전 평가에 있어서 합리적인 측정지표를 제시할 수 있을 것으로 기대된다.
\end{abstract}

\begin{abstract}
While the cost of technology development is increased, the life cycle of products and services that have been developed has become progressively shorter. Open innovation have been increasing by company as a strategy to respond to the rapidly changed market. Technology transfer from universities is one of the typical means of technological innovation. Although a university has invested significant resources in R\&D, the results has been neglected. Therefore, at the moment, research is needed about the outcomes and efficiency of technology transfer at universities. In the previous research, since most of studies focus on the analysis of factors that influence the outcome of technology transfer, in this study, targeting domestic universities, the efficiency of technology transfer at the university was analyzed. In addition, differences in the efficiency of different types of university is verified. Consequently, universities specializing in technology and industry has high-efficiency than the others. There is no significant difference between the groups of universities whether or not to participate in Technology Licensing Office(TLO). More efforts are required for successful results of TLO in Korea. This study is expected to be able to provide reasonable indicators on technology transfer for further research.
\end{abstract}

Key Words : Technology transfer, Technology Licensing Office(TLO), Industry-University Cooperation, DEA

\footnotetext{
"이 논문은 2009년도 정부(교육과학기술부)의 재원으로 한국연구재단의 지원을 받아 수행된 기초연구사업임 (NO. 2009-0073258)"

"Corresponding Author : Byungun Yoon

Tel: +82-10-2326-9519 email: postman3@dongguk.edu

접수일 12 년 03 월 30 일 수정일 (1차 12년 05월 02일, 2차 12년 05월 24일) 


\section{1. 서론}

세계 경제의 불확실성이 높아지고 경쟁이 심화되면서 기업들은 보다 확고한 우위를 점하기 위해 기술 경쟁력 강화에 집중하고 있다. 그러나 기술 개발에 소요되는 비 용이 증가하는 반면 기술 실현화를 통해 개발된 제품이 나 서비스의 수명주기가 점차 짧아지고 있다. 이에 기업 은 기술 혁신에 드는 비용을 절감하면서 빠르게 변화하 는 시장에 대응하기 위해 개방형 혁신(open innovation)에 대한 관심과 실행이 증가하고 있다. 여기에 기술 융합 (technology convergence)을 통해 이기종 기술을 서로 결 합하여 시너지 효과를 창출하고자 하는 혁신 활동도 많 아지고 있다. 이처럼 새로운 기술 개발의 흐름을 통해 볼 때, 더 이상 기업이 내부(in-house) 역량만을 활용하여 기 술 혁신을 꾀하는 것보다는 기업 내·외부의 경계를 허 물고 다양한 채널을 활용하여 기술 경쟁력 제고를 위한 노력이 필요하다는 것을 알 수 있다. 이 중 대표적인 공 공 연구기관인 대학과 기업이 연계하는 산학 활동이 증 가하고 있으며 정부에서도 이를 지원하기 위한 각종 지 원 정책 및 사업을 진행하고 있다.

우리나라는 1990년대 중반부터 산학협력의 중요성을 인식하기 시작하여 2004년을 기점으로 대학에 산학협력 단이 설치되면서 본격적인 지적재산권 권리화 및 기술 이전이 이루어지기 시작하였다. 그러나 대학의 기술이전 을 통해 발생된 수익은 2009년 대학 산학협력백서에 따 르면, 전체 연구비에 $0.6 \%$ 수준으로 그리 효율성이 높지 않는 것으로 분석되고 있다[1]. 그러므로 대학이 많은 자 원을 연구 개발에 투자하고 있음에도 불구하고 투여된 자원이 가져오는 결과를 적극적으로 고려하지 않는다고 볼 수 있다. 이러한 이유로 대학에서의 연구 성과와 기술 이전의 효율성에 대해 부정적인 견해가 지속적으로 제기 되고 있다.

이에 본 연구에서는 대학의 기술이전 건수와 그에 따 른 수입액을 기준으로 하여 대학의 역량, 산학협력단의 특성 및 $\mathrm{TLO}$ (기술이전 전담조직: Technology Licensing Office)의 특성이 효율성에 어떠한 영향을 미치는지를 $\mathrm{DEA}$ 를 활용하여 분석하고 이를 통해 프론티어 대학 즉, 효율성 $100 \%$ 을 달성한 대학의 특성을 분석하였다. 이를 통해 보다 효율적이고 성공적인 대학과 기업 간의 기술 이전을 위한 방향을 제시하였다. 그동안 기술이전과 관련 된 연구는 정부의 지원 등과 같은 기술이전 환경에 관한 연구와 기술이전 제도와 전략에 대한 연구가 중심적으로 이루어져 왔다. 대학 기술이전에 대한 연구도 주로 성과 를 중심으로 한 규모 중심의 연구는 진행되어 왔으나 상 대적인 효율성을 기반으로 한 연구는 미흡하였다. 따라서
본 연구에서는 현 단계에서 기술이전 효율성이 높은 대 학을 탐색하여 기술이전 효율성이 낮은 대학이 취해야 할 방안들이 무엇인지 제시하였다.

기술이전의 수요자인 기업의 입장에서 볼 때에 대학과 의 연계를 통한 기술 획득은 중요하다. 특히, $\mathrm{R} \& \mathrm{D}$ 를 위 한 자원 투입이 비교적 용이한 대기업과 달리 중소기업 들의 경우 대학에서 개발한 각종 기술들을 활용하여 자 사의 제품 및 서비스 경쟁력 제고를 꾀하고자 한다. 따라 서 대학이 보다 효율적으로 기술을 개발하여 지적재산권 을 확보하고 이를 통해 기술이전 건수 및 수익성이 높아 진다면 수요자와 공급자 모두 상생할 수 있는 결과라고 할 수 있다. 이에 국내 대학들은 산학협력단 및 TLO 부 서를 개설하여 운용하고 있으며, 국가에서는 '대학 TLO 육성 지원 사업'을 통해 국내 대학에 기술이전 전담 조직 의 설립 및 운영을 지원하고 있다. 본 연구에서는 이러한 TLO가 현재 대학의 기술이전 효율성에 영향을 미친다는 가정 하에 현재 대학에서 산학협력 및 기술이전을 위한 조직들의 기술이전 효율성을 분석하였다.

본 논문은 대학의 특성과 기술이전 효율성을 대학의 유형에 따라 비교하여 국내 대학의 기술 이전 효율성을 분석하였으며, 특히 대학 TLO 육성 지원 사업 참여에 따 른 기술이전 효율성 차이의 검정하였다. 이를 통해 국가 사업의 투자대비 효율성이 있는지를 살펴봄으로써 국내 대학 TLO 사업이 해외의 TLO 사업 대비 어느 정도의 위 치에 있는지에 대한 현황을 파악하였다. 이를 통해 향후 대학 중심의 기술이전 활성화를 위한 대학의 자체적인 투자나 운영 시스템을 재정비 하는데 활용될 수 있으며, 대학에 대한 국가적 차원에서의 지원 정책이나 $\mathrm{R} \& \mathrm{D}$ 전 략 수립에 활용할 수 있을 것으로 기대된다.

본 논문의 구성은 다음과 같다. 2 장에서는 기술이전에 대한 간략한 소개와 효율성 분석을 위해 활용한 DEA 방 법론을 소개하였으며, 3 장에서는 연구모형과 연구 방법 그리고 효율성 분석을 위해 활용한 데이터를 소개하였다. 4장에서는 효율성이 높은 대학과 낮은 대학을 비교 분석 하고 가설 검증을 통해 효율성을 높이기 위해 필요한 활 동이 무엇인지 분석하였다. 5 장의 고찰에서는 4 장에서 이루어진 분석 결과를 통해 대학에서의 기술이전 효율성 향상에 기여할 수 시사점을 도출하였다. 6장 결론에서는 현재 대학들의 기술이전 활동의 상대적 효율성을 분석한 결과를 요약하고 이를 통해 향후 대학들이 기술이전 효 율성 제고를 위한 가이드를 제시하였다.

\section{2. 이론적 배경}




\section{1 기술이전}

기술 이전 및 사업화 촉진에 관한 법률에 의하면 기술 이전이란 기술의 양도, 실시권 허락, 기술지도, 공동연구, 합작투자 또는 인수·합병 등의 방법을 통하여 기술보유자 로부터 그 외의 자에게 이전 되는 것을 말한다. 기초 연 구 및 인문, 예술, 사회과학 분야의 많은 연구가 대학에서 이루어지고 있으며, 대학이 창출하는 이러한 창의적 지식 은 상품과 서비스로 전환되어 산업의 발전에 원천이 되 기 때문에 대학에서의 기술이전은 국가 발전의 원동력으 로 인식되고 있다. 이에 따라 선진국들은 대학으로의 연 구개발 투자를 통해 대학의 지식활동 결과를 상업화함으 로써 경제 성장과 고용 창출을 도모하고 있다. 우리나라 는 2000년 "기술이전 촉진법” 제정 이후 기술이전 활동 에 대한 관심이 커지게 되었고, 국내 대학의 기술이전 및 사업화 실적은 꾸준히 증가하는 추세를 보이고 있다. 그 러나 2007년 기준으로 콜롬비아대학교이 162,759백만 원, MIT가 73,920백만 원 기술이전 수입을 창출한 것에 비하면, 국내 대학 중 가장 많은 기술이전 수익을 낸 서 울대학교의 기술이전 수입액이 3,082백만 원 수준으로 국내 대학의 기술이전 실적은 선진국에 비해 현저히 떨 어지는 수준이다.

이윤준 외(2009)는 대학에서의 기술이전의 저해요인 중 하나로 국내의 기술이전/사업화 전담기관의 규모가 작다고 지적했다. 2007년도 기준으로 미국의 주요대학의 평균 기술이전·사업화 전담인력이 15 명, 동경대가 20 명인 것에 비해 국내 대학은 3 명 수준에 불과했다[2].

\section{2 효율성과 DEA}

효율성을 측정하는 방식에는 여러 가지가 있다. 기존 의 문헌으로부터 도출된 생산 함수나 전문가들의 분석에 기초하여 기준을 설정하여 측정하는 방법은 특정한 함수 형태를 모든 산업에 동일한 것으로 가정한다는 점과 연 구자에 주관에 의존해야한다는 점에서 한계가 있다. 또 다른 방법은 유기적으로 기능을 수행하는 다른 조직과의 비교를 통해서 효율성을 측정하는 방법으로 상대적 효율 성이라고 한다.

DEA모형은 Charnes et al. (1978)에 의해 개발되었다. DEA모형은 선형계획법의 일종으로 하나 이상의 투입물 과 하나 이상의 산출물로 이루어진 의사결정 단위(DMU: Decision Making Units)를 유사한 속성을 가진 집단 내에 서 평가하는 상대적 평가기법이다[3]. 비모수적 접근방법 인 $\mathrm{DEA}$ 기법은 사전적으로 구체적인 함수형태를 가정하 고 모수를 추정하는 접근방법인 회귀모형과 달리 투입과 산출의 명확한 인과관계를 밝히기 어려운 의사결정단위
(DMU)의 상대적 효율성을 평가할 수 있다[4]. 또한 DEA 는 분석하는 $\mathrm{DMU}$ 들의 효율성을 제공할 뿐만 아니라 비 효율적인 $\mathrm{DMU}$ 가 모범으로 삼아야 할 $\mathrm{DMU}$ 를 제시해 줌 으로써 성과관리를 위한 구체적인 방향을 설정하고 지원 해 준다[5]. DEA는 비영리 의사결정 단위의 상대적 효율 성을 측정하는 방법으로 제시된 것이다. 이 방법은 투입 물과 산출물이 다수인 경우 유용하다. 이러한 투입물들을 결합하여 형성되는 산출물의 시장가격이 존재하지 않는 비영리 조직의 경우, 효율성은 절대적인 관점이아니라 상 대적인 관점에서 측정될 수밖에 없다는 기본 가정을 지 니고 있다[6].

이러한 DEA 모형의 유용성을 정리하면 다음과 같다. 첫째, 투입 변수와 산출 변수간의 특정한 함수 형태를 필 요로 하지 않으며, 이들에 대한 추가적인 평가를 필요로 하지 않는다. 둘째, 다수의 투입과 산출이 존재하는 경우, 이들을 적절한 방법으로 하나의 지수로 종합화하기 힘든 경우에 유용하게 사용될 수 있다. 셋째, 의사결정 단위의 투입, 산출 변수들이 동일한 척도의 크기를 가질 필요가 없다. 투입과 산출 요소들의 측정단위가 상이하거나, 화 폐 단위로 표시가 불가능할 때도 사용할 수 있으며, 재무 적 자료뿐만 아니라 비재무적 자료도 동시에 사용이 가 능하다. 넷째, 지수법에 비해 사전적 가중치가 필요치 않 아 자의적 주관을 배제할 수 있다.

$\mathrm{DEA}$ 모형을 대학에서의 기술이전 효율성을 측정방법 으로 선정하는 이유는 개별 대학 단위에 대한 기술이전 효율성 측정의 표준적인 방법이라는 것과 대학의 기술이 전이 다수의 투입물을 이용하여 다수의 산출물을 생산하 기 때문이다. 또, DEA 모형은 다수 투입요소와 다수 산 출물을 하나의 투입 및 산출가격으로 환산하지 않고 그 대로 사용할 수 있는 비모수적 모형이어서 다른 분석방 법에 비하여 대학의 기술이전 효율성을 측정하는데 유용 한 분석방법이 될 수 있다.

\section{3. 연구방법론}

\section{1 연구 프로세스}

국내 대학의 기술이전 효율성을 분석하기 위해 본 연 구는 그림 1 과 같이 진행하였다. 첫째, 대학에서의 기술 이전 현황을 기반으로 기술이전에 영향을 미치는 요인들 을 정의하고 요인간의 영향 및 관계를 연구모형으로 구 성하였다. 둘째, 연구모형을 바탕으로 대학의 기술이전에 관련된 데이터로 본 연구에서는 연구재단의 '산학협력실 태조사' 자료를 사용하였다. 셋째, 설문조사 결과를 분석 
[표 1] 효율성 분석을 위한 요인 정의

[Table 1] Definition of variables for efficiency analysis

\begin{tabular}{|c|c|c|c|c|}
\hline 구분 & \multicolumn{2}{|c|}{ 변수명 } & 조작적정의 & 단위 \\
\hline \multirow{2}{*}{$\begin{array}{l}\text { 성과요 } \\
\text { 인 }\end{array}$} & \multicolumn{2}{|c|}{ 기술이전 건수 } & $\begin{array}{l}\text { 4년간 대학으로부터 기술이전된 기술에 } \\
\text { 대한 연평균 기술이전 건수 }\end{array}$ & 건 \\
\hline & \multicolumn{2}{|c|}{ 기술이전 실적 수입액 } & $\begin{array}{l}\text { 4년간 대학이 기술이전 함으로써 창출한 } \\
\text { 수입액의 연 평균 값 }\end{array}$ & 백만 원 \\
\hline \multirow{9}{*}{$\begin{array}{l}\text { 영향요 } \\
\text { 인 }\end{array}$} & \multirow{3}{*}{$\begin{array}{l}\text { 대학 } \\
\text { 역량 }\end{array}$} & 연구전임요원 & 외국인을 포함한 전임강사 이상의 전임교원 수 & 명 \\
\hline & & 교내외 평균연구비 & $\begin{array}{l}\text { 전임강사 이상이 수주 받은 개인 연구비(교외/교내 연구비의 } \\
\text { 합) }\end{array}$ & 백만 원 \\
\hline & & 지식재산 합계 & $\begin{array}{l}\text { 2010년을 기준 학교법인 및 산학협력단 명의의 지식재산권 보 } \\
\text { 유 건수 } \\
\text { (국내/국제특허, 실용신안, 디자인/의장, 상표, 소프트웨어, 저 } \\
\text { 작권, 물질/물품) }\end{array}$ & 개 \\
\hline & \multirow{4}{*}{$\begin{array}{c}\text { 산학 } \\
\text { 렵력단 특성 }\end{array}$} & $\begin{array}{l}\text { 산학협력단 } \\
\text { 운영년수 }\end{array}$ & $\begin{array}{l}\text { 2010년도를 기준 운영 년도 수 } \\
\text { (2010년-설치년도) }\end{array}$ & 년 \\
\hline & & $\begin{array}{l}\text { 산학협력단 } \\
\text { 평균인력 }\end{array}$ & 산학협력단 고유 업무를 전담하여 수행하기 위한 인력의 수 & 명 \\
\hline & & $\begin{array}{c}\text { 특허등록 } \\
\text { 연구자 보상조항 }\end{array}$ & 특허등록 연구자 보상조항의 유무 & 유무 \\
\hline & & 기술이전 보상규정 & 기술이전 보상규정의 유무 & 유무 \\
\hline & \multirow{2}{*}{$\begin{array}{l}\text { 기술이전 } \\
\text { 전담부의 특성 }\end{array}$} & $\begin{array}{l}\mathrm{TLO} \text { 전담부서 } \\
\text { 운영년수 }\end{array}$ & $\begin{array}{l}\text { 2010년도를 기준 운영 년도 수 } \\
\text { (2010년-설치년도) }\end{array}$ & 년 \\
\hline & & $\begin{array}{l}\mathrm{TLO} \text { 전담부서 } \\
\text { 인력현황 }\end{array}$ & $\begin{array}{l}\text { 정규직, 계약직을 포함한 기술이전·사업화(TLO) 전담(주관)부 } \\
\text { 서 전체 인원 }\end{array}$ & 명 \\
\hline
\end{tabular}

에 맞게 적절히 가공하였다. 넷째, 연구모형을 토대로 대 학별 기술이전 성과에 따른 효율성을 실증적으로 분석하 였다. 다섯째, 대학을 유형별로 나누고 대학의 유형별로 기술이전 효율성이 어떤 차이를 보이는지 분석하였다.

\section{대학의 기술이전 효율성을 분석}

\section{연구모형 구성}

\section{데이터 수집}

\section{데이터 가공}

\section{효율성 분석 (DEA Model)}

대학 유형간 효율성 차이분석 (T-test, ANOVA)

[그림 1] 연구 프로세스

[Fig. 1] Research process

\section{2 기술이전 효율성 영향 요인 도출}

대학에서의 기술이전은 소속된 연구자들의 연구 활동 으로부터 시작된다. 인력, 자금 등의 자원이 투입된 연구 활동을 통해 보고서, 논문, 특허 등의 연구 성과물이 생성 되면 연구기관의 기술이전 조직은 성과물을 이전하기 위 한 활동을 전개한다[7]. 대학에서의 기술이전 성과는 주 로 기술이전 계약 건수나 기술이전 완료 건수, 기술이전 수입 또는 로열티 수입으로 측정되고 있다. 이에 본 연구 에서는 대학에서의 기술이전 효율성을 측정하기 위해 기 술이전 실적 건수와 기술이전 실적 수입액을 사용하였다. 기술이전 실적 건수는 설문조사 기간인 4년간 대학으로 부터 기술이전이 된 기술에 대하여 1 년에 평균 몇 건의 기술이전이 발생하였는가에 대한 것이며, 기술이전 실적 수입액은 4년간 기술이전으로 대학이 수입을 창출한 금 액에 대하여 1 년에 평균 어느 정도의 수입을 창출했는가 에 대한 것이다.

대학에서의 기술이전 성과에 영향을 미치는 요인은 여 러 가지가 있으며, 이러한 요인은 기술이전을 바라보는 시각에 따라 차이를 보일 수 있다. 본 연구에서는 각 대 학별 특성에 따른 기술이전 효율성을 분석하고자 대학의 역량, 산학협력단의 특성, 기술이전·사업화 전담부서의 
[표 2] 대학유형별 차이분석을 위한 유형 정의

[Table 2] Definition of university types

\begin{tabular}{|c|c|c|}
\hline \multicolumn{2}{|c|}{ 분류기준 } & 유형 \\
\hline \multirow{2}{*}{ 지역 } & 수도권 & \multirow{2}{*}{$\begin{array}{l}\text { 서울, 경기, 인천에 위치한 대학을 수도권으로, 그 이외 지역의 대학을 '지방' } \\
\text { 으로 구분 }\end{array}$} \\
\hline & 지방 & \\
\hline \multirow{2}{*}{ 규모 } & 대형 & \multirow{2}{*}{ 재학생 수를 기준으로 10000 명 이상을 대형, 그 이하를 중소형으로 구분 } \\
\hline & 중소형 & \\
\hline \multirow{2}{*}{ 설립목적 } & 일반대 & \multirow{2}{*}{$\begin{array}{l}\text { 설립목적에 특수성을 띄는 산업대와 기술특화대를 특화대로, 그 외의 대학 } \\
\text { 을 일반대로 구분 }\end{array}$} \\
\hline & 특화대 & \\
\hline \multirow{2}{*}{ 운영형태 } & 국공립 & \multirow{2}{*}{$\begin{array}{l}\text { 국가나 시도에서 운영하는 국립대학과 공립대학을 국공립으로, 재단 혹은 } \\
\text { 기업, 종교단체에서 운영하는 대학을 사립으로 구분 }\end{array}$} \\
\hline & 사립 & \\
\hline \multirow{2}{*}{$\begin{array}{l}\text { TLO 육성 } \\
\text { 지원 사업 }\end{array}$} & 시행 & \multirow{2}{*}{$\begin{array}{l}\text { 우리나라에서 2006년도부터 추진하는 대학 TLO육성 지원 사업을 시행하고 } \\
\text { 있는 대학과 그렇지 않은 대학으로 구분 }\end{array}$} \\
\hline & 시행 안함 & \\
\hline
\end{tabular}

특성에 따라 대학에서의 기술이전 성과가 영향을 받는다 고 가정하고 변수를 선정하였다.

첫 번째 영향요인인 대학의 역량이 기술이전 성과에 중요한 영향을 미친다는 것은 기존의 여러 연구를 통해 입증되었다. Power(2003)의 연구 결과 유명한 공대 교수 가 많을수록 대학에서의 기술이전 성과가 좋음을 밝혀냈 으며[8], 양종서(2005)의 연구결과에서도 대학의 인력자 원을 기술이전 성과의 영향요인으로 제시하였다[9]. 이에 본 연구에서 대학의 역량을 평가하는 요인 중 하나로 평 균 연구 전임교원 수를 포함하였다. 연구 전임교원 수는 외국인을 포함한 전임강사 이상의 전임교원으로 설문조 사가 진행되는 4년 동안 연구 전임교원의 수에 변동이 있 는 경우 평균값을 사용하였다. 겸임, 명예, 대우, 초빙 인 원 등은 연구 전임교원 수에서 제외하였다. 또한 교내외 평균 연구비는 전임강사 이상이 수주 받은 개인 연구비 로 교외(정부, 민간 지자체 연구비 등)와 교내(대학자체 연구비)를 합한 값으로, 4 년 동안의 연구비의 평균값을 사용하였다. 김철회, 이상돈(2007)의 연구 결과에서 SCI 논문수와 특허등록건수는 기술이전 수입료와 기술이전건 수에 유의미한 영향을 미친다고 밝힌바 있으며[10], 김경 환, 현선해(2006)의 연구에서는 대학보유 특허 수가 대학 에서의 기술이전에 유의한 영향을 미치는 것으로 나타났 다[11]. 본 연구에 사용된 지식재산 수는 2010년을 기준 으로 대학이 보유하고 있는 총 지식 재산의 수로 학교법 인 및 산학협력단 명의의 지식재산권 보유 건수를 의미 하며, 지식재산권에는 국내·국제특허등록, 실용신안, 디 자인/의장, 상표, 소프트웨어, 저작권, 물질/물품이 포함된 다.

두 번째 영향요인인 산학협력단의 특성을 나타내는 변
수로는 산학협력단 설립년수, 산학협력단 인력현황, 특허 등록 연구자 보상조항과 기술이전 보상규정이 있다. 산학 협력단 설립년수는 2010년을 기준으로 산학협력단이 몇 년째 운영되고 있는지에 관한 변수이며, 산학협력단 인력 현황은 국책사업관리, 기간제 파견 및 겸직, 교원 겸직을 제외하고, 산학협력단 고유 업무를 전담하여 수행하기 위 한 인력의 수를 의미한다. 기술이전 성과보상[12]이나 발 명자에 대한 인센티브[13], 기술이전을 통하여 발생되는 로열티 수입을 발명자에게 분배해 주는 것[14]이 효과적 인 기술이전 성과를 창출한다는 연구결과와 보상시스템 운영체계의 미흡이 기술이전의 장애요인으로 분석한 Siegel(2003)의 연구 결과를 바탕으로 특허등록 연구자 보상조항의 유무와 기술이전 보상규정의 유무를 기술이 전 성과의 영향요인으로 추가하였다[15]. 이 두 변수는 4 년간 대학이 보상규정을 시행하였으면 4점, 3년간 시행 하였으면 3점, 4 년간 보상규정이 없었으면 0점으로 환산 하여 측정하였다.

마지막으로 번창률(2004)와 Power(2003)은 기술이전 조직의 연혁을 기술이전 성과요인으로 제시하였는데, 오 래된 기술이전 전담조직을 가질수록 기술이전 성과가 좋 다는 연구결과를 제시하였다[8][13]. 이에 따라 본 연구에 서는 기술이전·사업화 전담부서 설치년수를 기술이전 성 과의 영향요인으로 제시하였다. 기술이전·사업화 전담부 서 설치년수는 2010년도를 기준으로 몇 년째 운영되고 있는지에 관한 변수이다. 기술이전-사업화 전담부서 인력 현황은 정규직, 계약직을 포함한 전체 인원을 의미한다. 기술이전에 영향을 주는 요인과 성과측정 요인은 표 1 과 같이 요약된다. 


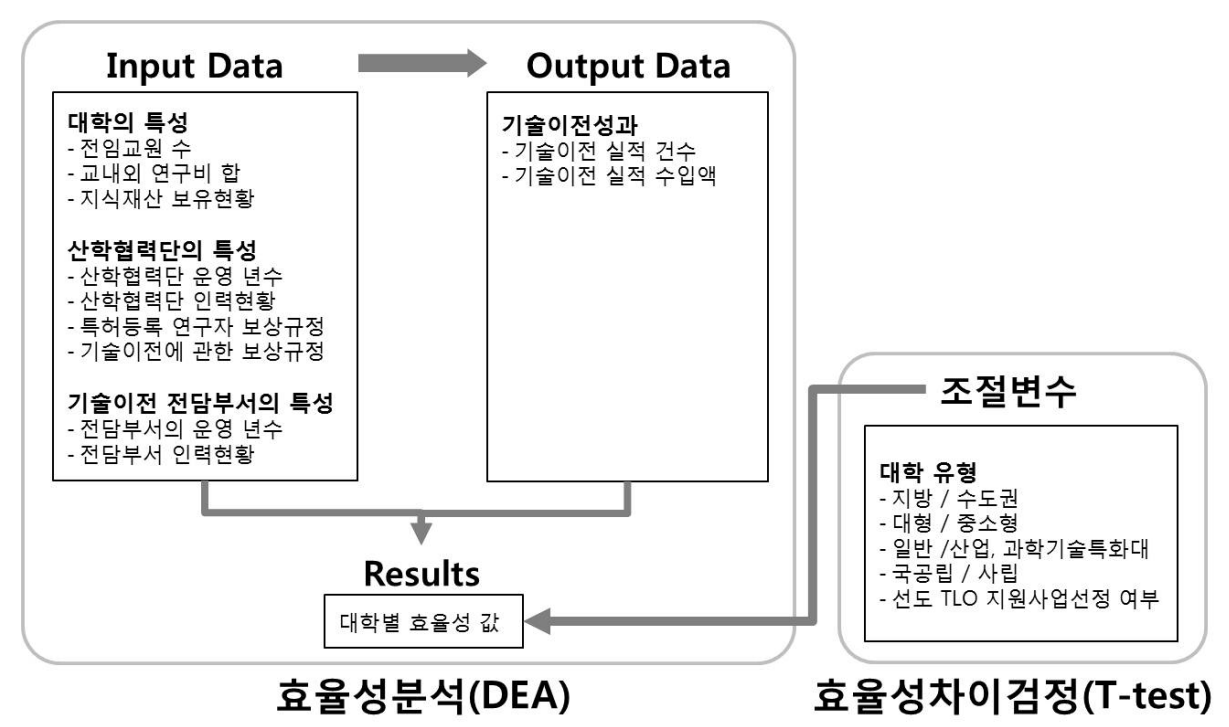

[그림 2] 연구모형

[Fig. 2] Research model

\section{3 대학유형에 따른 분류}

효율성 차이를 검증하기 위한 대학의 유형을 분류 기 준에 따라 표 2와 같이 다섯 가지로 유형화하였다.

첫 번째 분류기준은 지방/수도권이다. 서울, 경기, 인 천에 위치한 대학을 '수도권'으로 분류하고, 그 이외 지 역에 위치한 대학을 '지방'으로 분류하였다. 두 번째 분 류기준은 대형/중소형이다. 대형대학과 중소형대학의 구 분은 2003년의 '교육인적자원부 대학 특성화 사업'과 2009년의 '대학 연구활동 실태 보고서'에서 사용되었던 것과 같이 재학생 수를 기준으로 10,000 명 이상을 대형 그 이하를 중소형으로 분류하였다. 세 번째 분류기준은 설립목적이다. 대학을 일반대학과 특수성을 띄는 산업대 및 기술특화대로 분류하였다. 네 번째 분류기준은 국공립 /사립이다. 마지막 분류기준은 대학의 TLO 육성 지원 사 업선정 여부이다. 대학에서 학술적 연구 및 교육 뿐 아니 라 대학에서의 발명의 결과로 얻은 기술을 이전하는 메 커니즘을 구축하는 것은 경제발전의 밑거름이 되는 중요 한 요소이다. 교육뿐만 아니라 학술적인 측면에서 대학은 연구의 결과를 산업으로 전달하는 것은 국가기술력 향상 에 기여하는 중요한 요소이다. 이러한 대학에서의 기술이 전에는 몇 가지 한계점이 존재한다. 먼저 연구자가 기술 의 수요자를 찾기 쉽지 않다는 것과 연구에 대한 재산권 을 보호받는데 소요되는 비용이 적지 않다는 것이다. 이 에 대해 선진국의 대학에서는 발명에 대한 권리 취득 및 기술이전을 원활하게 하기 위한 기구를 설치하여 운영하
고 있는데, 이를 TLO라 한다.

우리나라에서는 2006년도부터 교육과학기술부와 지식 경제부가 공동으로 추진하는 대학 TLO 육성 지원 사업 을 통해 기술이전 전담조직의 인건비, 기술이전 사업화에 소요되는 비용 등을 지원하고 있다. 지난 5년간(2006 2010) 1단계 대학 TLO 육성 지원 사업을 통하여 2006년 사업 초기 64 억에 불과하던 18 개 대학의 기술료 수입이 2010년 248억으로 5년간 388\% 증가하는 등 그 성과가 가시화 되고 있다. 대학 TLO 육성 지원 사업은 대학의 지식재산 가치를 증가시키고, R\&D 생산성 향상과 기술 사업화를 통해 대학의 연구력 제고와 국가 경쟁력 강화 에 크게 기여하였다. 본 연구에서는 대학 TLO 육성 지원 사업이 실시된 이래 2007년 2010년까지 4년간의 데이 터를 통해 대학 TLO 육성 지원 사업 대상 대학과 아닌 대학 간의 기술이전 효율성의 차이를 검증함으로써 대학 $\mathrm{TLO}$ 육성 지원 사업의 성과를 평가하고자 한다.

\section{4 연구 모형}

본 연구는 대학에서의 기술이전의 효율성을 분석하고 대학의 유형별로 효율성이 다른지 차이를 검정하기 위한 것이다. 본 연구에서는 2007년부터 2010년까지 4년간 연 구재단에서 설문조사를 실시한 '산학협력실태조사' 자료 를 근거로 분석하였다. 이 자료는 설문조사 실시기간인 4 년간 국내소재 387 개 대학에서 기술이전 된 4,342건의 데이터를 포함하고 있다. 이 중 4 개년의 데이터가 모두 
존재하는 118 개의 대학을 선별하였고, 118 개의 대학 중 기술이전 실적이 없는 31 개의 대학을 제외한 87 개의 대 학이 본 연구의 분석 자료로 사용되었다.

대학의 기술이전 효율성을 분석하기 위해 본 연구에서 는 앞서 언급했듯이 DEA 분석을 수행하였다. 표 1과 같 이 성과 요인과 영향 요인을 분류하여 표본 데이터를 분 석하였다. DEA 분석에는 Frontier Analyst Professional 3.0 을 활용하였으며, CCR 모형으로 분석하였다. 이후 조 절변수의 역할을 확인하기 위해서 가설을 설정하고 이를 검정하기 위해 t-test와 카이제곱 검정을 실시하였다. 그 래서 대학 유형이 대학의 기술이전 효율성에 미치는 영 향을 확인하였다. 그림 2 는 본 연구의 모형을 제시한 것 이다.

\section{4. 기술이전 성과 실증분석}

\section{1 대학별 기술이전 효율성 분석}

효율성 분석을 위해 DEA분석 소프트웨어인 Frontier Analyst Professional 3.0을 사용하였다. 이 소프트웨어는 한 데이터 세트에 포함되어 있는 각 데이터에 대해 선형 프로그래밍(LP)을 적용하여 문제를 해결하는 방식을 사 용한다. 이 소프트웨어에서 입력 및 출력변수의 가중치, $\mathrm{CCR}$ 또는 $\mathrm{BCC}$ 모형, 목적함수의 방향을 설정할 수 있 다. 본 연구에서는 각 변수에 대해 동일한 가중치를 사용 하는 CCR 출력입력방향 모델을 사용하였다. 각 대학의 기술 통계 및 독립표본 t검정은 SPSS(Ver. 20.0)을 활용 하였다.

분석에 따르면, 103 개의 대학 중 23 개의 대학이 $100 \%$ 의 효율성 값을 가지며, 이 대학들은 프론티어 대학으로 효율성이 $100 \%$ 에 미치지 못하는 타 대학의 벤치마킹 대 상이 된다. 효율성 값이 $100 \%$ 인 대학을 제외한 80 개 대 학의 평균 효율성 값은 $34.18 \%$ 로 나타났다. 표 3은 대학 별 효율성 분석 결과 값의 도수분포표이다.

$100 \%$ 의 효율성을 갖는 대학을 제외한 80 개 대학 중 효율성 값이 상위 $20 \%$ 에 속하는 고효율군 대학과 하위 $20 \%$ 에 속하는 저효율군 대학 간에는 각 입력변수 별로 어떤 차이를 보이는지 검증하기 위해 고효율군 대학과 저효율군 대학의 효율성 입력변수 별 독립표본 $\mathrm{t}$ 검정을 실시하였다. 분석 결과는 표 4와 같다. 분석결과, 연구전 임요원의 수는 고효율 군이 저효율군 보다 1.5 배 이상 많 았으며, 교내외 평균연구비는 3.6배 이상 높게 나타났다. 지식재산권 역시 고효율군 대학이 저효율군 대학보다 4.2 배 이상 높았다. 고효율군의 대학은 저효율군의 대학보다 특허등록 보상규정을 실시한 기간이 더 길었으며, 기술이
전건수와 기술이전 실적수입액 또한 높았다. 하지만 산학 협력단 운영년수는 오히려 고효율군 대학이 저효율군의 대학보다 낮게 나타났으며, TLO 전담부서의 운영 기간 과 운영 인력은 두 집단 간의 차이가 없는 것으로 나타났 다. 이는 우리나라보다 먼저 TLO을 활용하여 대학의 기 술이전 효율성을 높이고자 했던 일본에서도 10 년이 지난 후 본격적인 성과가 나타난 것을 볼 때, 국내 대학에 설 치되어 있는 $\mathrm{TLO}$ 는 아직 성과를 낼 수 있을 정도로 성숙 되지 않았다고 볼 수 있다[12].

[표 3] 대학의 기술이전 효율성 값 분포

[Table 3] Distribution of technology transfer efficiency

\begin{tabular}{|c|c|}
\hline 효율성 값(\%) & 도수 \\
\hline \hline 100 & 23 \\
\hline $91 \sim 99.9$ & 0 \\
\hline $81 \sim 90$ & 3 \\
\hline $71 \sim 80$ & 4 \\
\hline $61 \sim 70$ & 4 \\
\hline $51 \sim 60$ & 8 \\
\hline $41 \sim 50$ & 8 \\
\hline $31 \sim 40$ & 11 \\
\hline $21 \sim 30$ & 16 \\
\hline $11 \sim 20$ & 12 \\
\hline $0 \sim 10$ & 14 \\
\hline 총합 & 103 \\
\hline
\end{tabular}

[표 4] 효율성 입력변수별 고효율군 및 저효율군의 독립 표본 $\mathrm{t}$ 검정 결과표

[Table 4] Results of t-test with input variables in groups of University

\begin{tabular}{|c|c|c|c|c|}
\hline 변수 & $\begin{array}{l}\text { 고효율군 } \\
\text { 평균 }\end{array}$ & $\begin{array}{c}\text { 저효울군 } \\
\text { 평균 }\end{array}$ & $\begin{array}{c}\text { t-value } \\
\text { (I-J) }\end{array}$ & $\begin{array}{l}\text { 유의 } \\
\text { 확률 }\end{array}$ \\
\hline 효율성 & 65.987 & 8.910 & 19.395 & $.000 * * *$ \\
\hline 연구전임요원 & 580.270 & 383.695 & 1.738 & $.001 * * *$ \\
\hline $\begin{array}{c}\text { 교내외 } \\
\text { 평균연구비 }\end{array}$ & 45801.81 & 12568.00 & 2.630 & $.000 * * *$ \\
\hline 지식재산 합계 & 305.81 & 71.57 & 2.659 & $.000 * * *$ \\
\hline $\begin{array}{l}\text { 산학협력단 } \\
\text { 운영년수 }\end{array}$ & 6.00 & 6.14 & -1.826 & $.000 * * *$ \\
\hline $\begin{array}{l}\text { 산학협력단 } \\
\text { 평균인력 }\end{array}$ & 24.353 & 19.064 & 1.163 & .301 \\
\hline $\begin{array}{l}\text { 특허등록 } \\
\text { 보상규정 }\end{array}$ & 3.67 & 3.10 & 2.055 & $.002 * * *$ \\
\hline $\begin{array}{l}\text { 기술이전 } \\
\text { 보상규정 }\end{array}$ & 3.48 & 3.43 & .162 & .825 \\
\hline $\begin{array}{l}\text { TLO전담부서 } \\
\text { 운영년수 }\end{array}$ & 6.00 & 6.10 & -.139 & .742 \\
\hline $\begin{array}{c}\text { TLO 전담부서 } \\
\text { 인력현황 }\end{array}$ & 4.127 & 3.381 & .879 & .405 \\
\hline 기술이전건수 & 17.05 & 1.48 & 4.722 & $.000 * * *$ \\
\hline $\begin{array}{l}\text { 기술이전 } \\
\text { 실적수입액 }\end{array}$ & 279.639 & 22.488 & 3.612 & $.000 * * *$ \\
\hline
\end{tabular}

***: $95 \%$ 유의수준 


\section{2 대학 유형별 효율성 차이 검정}

대학의 유형에 따라 대학에서의 기술이전 효율성에는 차이가 있을 것이라는 가설 하에 대학의 유형에 따른 효 율성 값의 차이를 살펴보았다. 이전 단계에서 $\mathrm{DEA}$ 를 통 해 산출된 효율성 값을 토대로 대학이 위치한 지역(수도 권/지방)에 따라 효율성 값에 차이가 있는지, 대학 규모별 (대형/중소형)에 따라 효율성 값에 차이가 있는지, 일반대 학과 특화대학 간 효율성 값에 차이가 있는지, 국공립 대 학 및 사립대학 간 효율성 값에 차이가 있는지, 대학 TLO 육성 지원 사업 선정 여부에 따라 대학 간 효율성 값에 차이가 있는지 여부에 대하여 독립표본 t검정을 사 용하여 검증하였다.

가설1. 대학이 위치한 지역(수도권/지방)에 따라 효율 성 값에는 차이가 있을 것이다.

가설2. 대학 규모별(대형/중소형)에 따라 효율성 값에 는 차이가 있을 것이다.

가설3. 대학의 설립목적(일반대/특화대)에 따라 효율 성 값에는 차이가 있을 것이다.

가설4. 대학의 운영형태(국공립/사립)에 따라 효율성 값에는 차이가 있을 것이다.

가설5. 대학 TLO 육성 지원 사업 시행 여부에 따라 효 율성 값에는 차이가 있을 것이다.

대학 유형별 효율성 값의 차이 검정에는 통계 software 인 IBM SPSS statistics 20이 사용되었다. 표 5에 제시한 바와 같이, 대학의 설립 목적에 따라 기술이전의 효율성 값에 차이를 보였으며(유의확률: 0.001 ), 기술대와 산업대 와 같이 특화된 대학은 일반 대학보다 효율성 값이 1.8 배 이상 높았다. 그러나 다른 유형요인에 대해서는 효율성의 유의한 차이는 볼 수 없었다.

[표 5] 대학유형에 따른 기술이전 효율성 차이에 대한 독 립표본 $\mathrm{t}$ 검정

[Table 5] Result of t-test on technology transfer efficiency in University types

\begin{tabular}{|c|c|c|c|c|}
\hline 분류기준 & 유형 & 평균 & $\mathrm{t}$ & 유의확률 \\
\hline \multirow{2}{*}{ 지역 } & 수도권(I) & 46.0114 & \multirow{2}{*}{-.564} & \multirow{2}{*}{.574} \\
\hline & 지방(J) & 49.9691 & & \\
\hline \multirow{2}{*}{ 규모 } & 대형(I) & 43.3331 & \multirow{2}{*}{-1.647} & \multirow{2}{*}{.103} \\
\hline & 중소형(J) & 54.4292 & & \\
\hline \multirow{2}{*}{ 설립목적 } & 일반대(I) & 45.0632 & \multirow{2}{*}{-3.361} & \multirow{2}{*}{$.001 * * *$} \\
\hline & 특화대(J) & 81.4410 & & \\
\hline \multirow{2}{*}{ 운영형태 } & 국공립(I) & 56.1464 & \multirow{2}{*}{1.556} & \multirow{2}{*}{.123} \\
\hline & 사립(J) & 45.0355 & & \\
\hline \multirow{2}{*}{$\begin{array}{l}\text { TLO } \\
\text { 사업 }\end{array}$} & TLO시행(I) & 48.8161 & \multirow{2}{*}{.075} & \multirow{2}{*}{.941} \\
\hline & 시행안함(J) & 48.3157 & & \\
\hline
\end{tabular}

***: $95 \%$ 유의수준

\section{3 대학 유형별 프론티어 대학 선정의 차이 검정}

앞서 언급한 것처럼, $100 \%$ 의 효율성 값을 가지는 대 학들은 프론티어 대학으로서 효율성이 $100 \%$ 에 미치지 못하는 타 대학의 벤치마킹 대상이 된다. 효율성이 $100 \%$ 에 미치지 못하는 각 대학의 변수들을 고려하여 가장 쉽 게 벤치마킹 할 수 있는 대학을 선정하게 되는데, 그림 3 은 효율성이 $100 \%$ 인 대학들이 그렇지 않은 대학들로부 터 몇 번 프론티어 대상으로 선정 되었는지를 보여주고 있다. 막대그래프의 가장 위에 있는 72 번 대학은 효율성 이 $100 \%$ 에 미치지 못하는 각 대학으로부터 59 번 프론티 어 대학으로 선정되었으며, 97번 대학은 52번, 4 번 대학 은 38 번 프론티어 대학으로 선정됨을 의미한다.

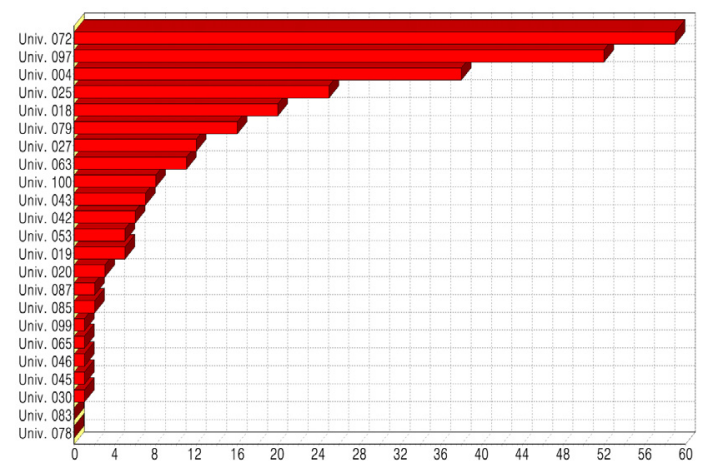

[그림 3] 프론티어 대학별 프론티어 대상 선정 횟수

[Fig. 3] Counts of frontier selection

프론티어 대학으로 선정된 대학은 대학의 유형별로 유 형별 프론티어 대학으로 선정되는 비율이 다를 것이라는 가정 하에 다음과 같은 가설을 설정하여 검증하였다. 대 학의 유형은 명목척도이므로 카이제곱 검정을 실시하였다.

가설 1: 대학의 운영형태가 국공립인지 사립인지에 따 라 프론티어로 선정된 비율이 다를 것이다.

가설 2: 대학이 위치한 지역이 수도권인지 지방인지에 따라 프론티어로 선정된 대학의 비율이 다를 것이다.

가설 3: 대학의 규모가 대형인지 중소형인지에 따라 프론티어로 선정된 대학의 비율이 다를 것이 다.

가설 4: 대학의 설립목적이 일반대인지 특수대인지에 따라 프론티어로 선정된 비율이 다를 것이다.

가설 5: 대학 TLO 육성 지원 사업의 참여 여부에 따라 프론티어로 선정된 비율이 다를 것이다. 


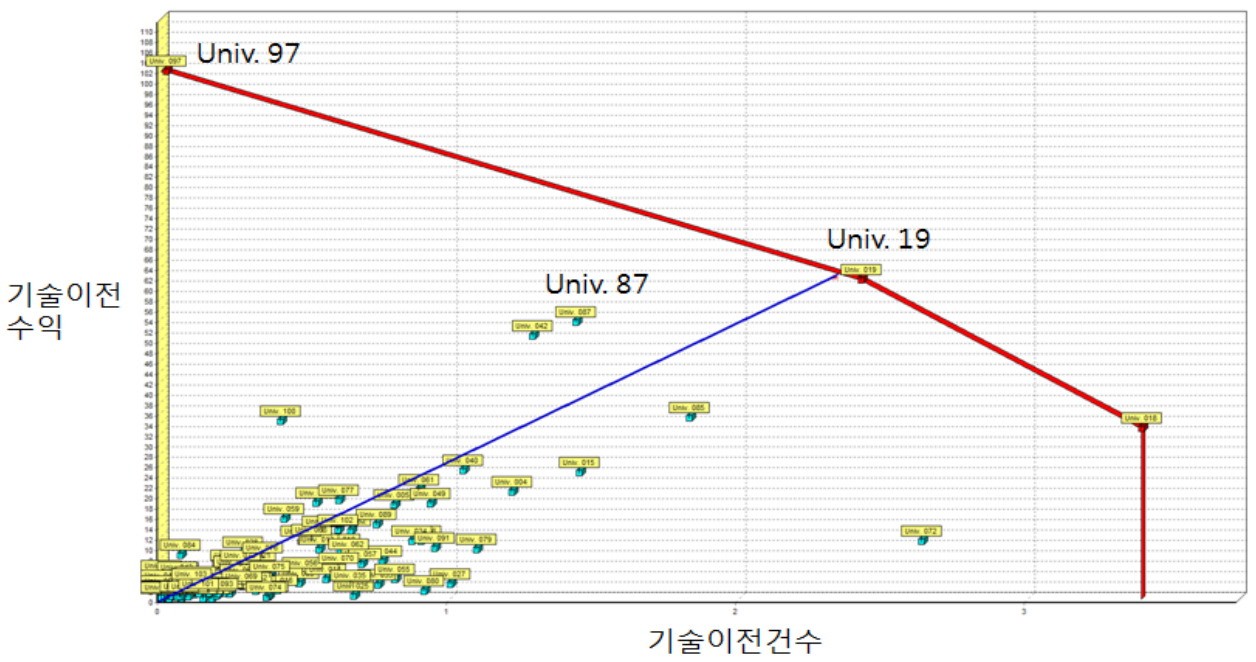

[그림 4] 산학협력단 평균 인력 측면의 효율성 제고 전략 예시

[Fig. 4] Example of a strategy to improve technology transfer efficiency in terms of human resources

[표 6] 대학유형별 프론티어 교차분석 결과

[Table 6] Result of chi-square analysis on frontiers in University types

\begin{tabular}{|c|c|c|c|c|}
\hline & 구분 & $\begin{array}{l}\text { 프론티어/ } \\
\text { 전체빈도 }\end{array}$ & $\begin{array}{c}\text { 대학유형 } \\
\text { 중 } \%\end{array}$ & $\begin{array}{l}\text { 카이제곱 } \\
\text { 유의확률 }\end{array}$ \\
\hline \multirow{2}{*}{ 국공립/사립 } & 국공립 & $10 / 33$ & 30.3 & \multirow{2}{*}{.182} \\
\hline & 사립 & $13 / 70$ & 18.6 & \\
\hline \multirow{2}{*}{ 지역 } & 수도권 & $7 / 36$ & 19.4 & \multirow{2}{*}{.606} \\
\hline & 지방 & $16 / 67$ & 23.9 & \\
\hline \multirow{2}{*}{ 규모 } & 대형 & $8 / 54$ & 14.8 & \multirow{2}{*}{$.055^{* *}$} \\
\hline & 중소형 & $15 / 49$ & 30.6 & \\
\hline \multirow{2}{*}{ 일반/특수대 } & 일반대 & $16 / 93$ & 17.2 & \multirow{2}{*}{$.000 * * *$} \\
\hline & 특수대 & $7 / 10$ & 70.0 & \\
\hline \multirow{2}{*}{ TLO사업 } & 유 & $14 / 52$ & 26.9 & \multirow{2}{*}{.258} \\
\hline & 무 & $9 / 51$ & 17.6 & \\
\hline
\end{tabular}

다섯 가지 가설에 대한 분석 결과는 표 6과 같다. 대학 이 국공립인지 사립인지, 대학이 위치한 지역이 수도권인 지 지방인지, 대학이 대학 TLO 육성 지원 사업에 참여 했는지 여부와 효율성 $100 \%$ 인 프론티어 대학으로 선정 되는 것에는 상호 연관성이 없었다. 하지만 대학의 규모 가 대형인지 중소형인지에 따라 프론티어 대학로 선정된 대학의 비율에는 차이를 보였으며, 대형대학보다 중소형 대학에서 프론티어 대학으로 선정된 확률이 높았다. 또 한, 대학이 일반 대학인지 기술대와 산업대 같은 특수한 목적을 지닌 특화 대학인지에 따라서도 프론티어로 선정 된 대학의 비율에는 확연한 차이를 보였다(유의확률 0.000 ). 특화대 중 $70 \%$ 는 프론티어 대학으로 선정되었고,
일반 대학 중에서는 $17.2 \%$ 만이 프론티어 대학으로 선정 되었다. 이는 특화대로 분류된 산업대와 과학기술대가 기 술이전 수요자들인 기업의 측면에서 볼 때에 보다 가치 가 있는 기술을 개발하고 있음을 확인할 수 있다. 실제 산업대의 경우 현업 전문가들을 학교의 교원으로 초빙해 산학협력의 매개(gatekeeper)로 활용하고 있어 기술이전 수요자의 요구사항을 반영한 기술 개발 및 이전을 꾀하 고 있으며, 과학기술대는 원천 기술 개발에 집중함으로써 파급력이 높은 기술을 이전하여 높은 효율성을 거두고 있다. 이로 인해 효율성이 높은 프론티어 대학은 주로 특 화대에 집중되어 있음을 확인할 수 있다.

그림 4는 $\mathrm{DEA}$ 의 여러 입력변수 중 산학협력단 평균 인력 측면이 두 가지 출력변수 즉, 성과 요인인 기술이전 건수와 기술이전 수익(세로축)에 따라 각 대학들의 효율 성을 보여주고 있다. 그래프의 가로축은 산학협력단 평균 인력 대비 기술이전 건수를 나타내며 세로축은 산학협력 단 평균 인력 대비 기술이전 실적액을 나타낸다. 그림에 서 테두리에 있는 대학들이 효율성 $100 \%$ 에 해당하는 프 론티어 대학을 의미하며 원점에서 테두리에 이르는 선은 효율성 $100 \%$ 에 도달하기 위한 방향을 보여주고 있다. 원 점에서 출발하는 선을 기준으로 선의 위쪽에 위치하는 대학은 기술이전 건수보다 기술이전 실적액이 많은 대학 이고, 선의 아래쪽에 위치하는 대학은 기술이전 실적액이 기술이전 건수보다 많은 대학이다. 또한 아직 효율성 $100 \%$ 에 이르지 못한 대학들의 경우 프론티어 대학들의 성과요인들을 중심으로 목표를 수립하여 달성하도록 한 
다면 보다 기술이전 효율성을 높일 수 있다고 본다. 예를 들어 87 번 대학은 효율성 $100 \%$ 인 테두리에 접근하기 위 해 가장 가까운 경로를 찾고, 이를 벤치마킹함으로써 효 율성을 높이는 전략을 세울 수 있다.

\section{5. 고찰}

미국과 일본 등과 같은 국가에서는 일찍이 대학을 연 구자원으로 활용하여 기업의 기술력 향상을 도모하기 위 해 기술이전 사업에 관심을 갖고 여러 제도적 지원해왔 다. 우리나라에서는 2004년부터 대학에 산학협력단을 설 치하기 시작하였고, 2006년에는 대학 TLO 육성 지원 사 업이 시작하면서 본격적으로 대학에서의 기술이전에 관 심을 갖기 시작하였다. 이후 대학 TLO 전담 부서로의 국 가적 지원이 활기를 띠게 되었다. 이 지원 사업에 대해 현재까지 2010년도까지의 설문조사를 통해 데이터가 확 보되어 있으며, 이 시점에서 대학이 보유하고 있는 각기 다른 자원들과 이 지원 사업이 결합되어 나타나는 성과 물을 효율성 측면에서 살펴봄으로써 상대적으로 효율성 이 낮은 대학은 효율성이 높은 대학을 벤치마킹 하여 효 율성을 향상시킬 수 있다. 특히 한 대학이 가진 자원과 유사한 자원을 가지고 있지만 효율성이 높은 대학을 벤 치마킹하여 효과적인 효율성 향상이 기대 된다.

기술이전의 효율성 측면에서 국내 대학의 약 $20 \%$ 는 효율적으로 기술이전을 하는 것으로 나타났다. 효율성이 높은 대학과 낮은 대학을 비교한 결과를 통해 효율성이 높은 대학은 효율성이 낮은 대학보다 연구 전임 교원이 많고, 평균 연구비도 높다는 것을 알 수 있었다. 다시 말 해, 연구 전임 교원이 많을수록 기술이전의 절대적 수치 뿐 만 아니라 효율성도 높았다. 연구 전임 교원이 많은 대학은 대학 내의 연구 전임 교원간의 지식 교환이나 합 작 기술연구 등의 긍정적인 교류를 통해 기술이전 효율 성이 높아진 것으로 보인다. 또한 연구비가 많이 할당 될 수록 연구비 대비 성과물이 컸다. 여기서 눈여겨 볼 결과 는 대학 TLO육성 지원 사업의 참여 여부가 기술이전에 큰 영향을 미치지 못한 다는 것이다. 본 연구의 목적 중 하나는 기술이전 효율성이 대학 TLO 육성 지원 사업에 참여 했는지의 여부에 따라 기술이전 효율성에 미치는 영향을 검증하는 것 이였으나, 실제 분석 결과 TLO 지원 사업의 여부와 기술이전 성과 사이에는 유의미한 관련성 이 나타나지 않았다. 이것은 TLO 전담부서가 설치되고 운영하는 등의 투자가 국가적 차원에서 이루어지고 있지 만 아직까지 그 실효성을 거두지 못하고 있음을 알려준 다. 이는 유사한 조직을 보유하고 있는 일본의 경우를 비
추어 보았을 때, 일본에서는 TLO 관련 사업을 시행한지 10 년이 지난 이후에야 본격적인 성과 나타나기 시작했다. 이런 점을 고려할 때 국내 대학에 설립된 TLO은 아직 성 과를 창출할 만큼 성숙되지 못했으나 지속적인 지원 사 업을 통해 TLO 전담부서의 운영 효율성이 증가 될 것이 라 기대된다.

또한 외국대학을 대상으로 분석한 기존 연구와는 달리 국내에서는 산학협력단의 운영년수가 짧을수록 기술이전 의 효율성이 높게 나타났다. 이것은 초기 국내에 설치된 산학협력단은 연구관리 위주의 행정업무를 위해 설치되 었으나 최근에 설립되는 산학협력단은 연구 관리와 더불 어 연구된 기술의 사업화나 기술이전과 같은 업무를 병 행할 수 있는 프로세스를 갖추고 있기 때문으로 볼 수 있다.

기술대나 산업대와 같은 특화대의 기술이전 효율성은 일반대보다 높게 나타났다. 프론티어로 선정된 대학의 수 를 비교한 결과에서도 유사한 결과를 나타내고 있는데, 특화대 중 프론티어로 선정된 특화대의 비율이 일반대 중 프론티어로 선정된 일반대의 수보다 많았다. 대학은 기술에 대한 높은 지식을 보유함으로써 기술이전의 효율 성을 높일 수 있고, 산업대와 같이 산업현장의 인력을 교 육과 연관시킴으로써 기술이전의 효율성을 높일 수 있다. 이러한 관점에서 볼 때, 산업에 종사한 인력을 산학협력 관련 부서에 배치하거나 주기적인 소통을 가짐으로써 대 학은 산업에서 필요로 하는 기술에 집중할 수 있게 되고 산학협력단 운영의 효율성도 증가시킬 수 있을 것이다.

\section{6. 결론}

본 연구는 대학에서의 기술이전의 효율성을 분석한 후 대학의 유형별 효율성의 차이를 검증하였다. 검증 결과 대학이 위치한 지역과 대학의 규모, 대학의 운영 형태에 따른 효율성 값의 유의한 차이에는 없었다. 반면 일반 대 학보다 목적성이 있는 특화 대학에서 기술이전 효율성이 높은 것으로 분석되었다. 즉, 산업대나 기술대와 같은 특 화 대학은 특수한 목적에 맞게 설립된 대학으로 전문적 인 기술에 대한 높은 지식을 보유함으로써 기술이전 성 과에 영향을 미치고 있기 때문으로 보여 진다. 산업대와 같이 현장 인력을 지속적으로 수급하여 교육 및 기술개 발 활동을 장려함으로써 수요가 있는 기술을 획득, 기술 이전하는 노력이 필요하며 기술대와 같이 파급력이 있는 원천 기술을 개발하여 기술이전에 활용하는 전략적인 활 동이 필요함을 알 수 있었다.

대학 TLO 육성 지원 사업 참여 여부에 따른 대학에서 의 기술이전의 효율성에는 유의한 차이가 없었다. 이는 
먼저 TLO 사업을 실시한 일본에서도 10 년이 지난 후부 터 본격적인 성과가 나타난 것을 감안해 볼 때에 아직 국 내에 TLO의 성숙도가 성과나 효율성에 연계되기에는 낮 은 것으로 분석할 수 있다. 또한, 단순히 TLO 사업에 지 원을 하는 것이 중요한 것이 아니라 앞서 언급한 특성화 대학들이 기술이전 효율성이 높은 것을 볼 때에 각 대학 별 TLO가 기술이전 수요자들이 요구하는 사항들이 무엇 인지를 파악하여 전략적으로 기술을 획득하고 이전할 수 있는 방안이 필요하다고 볼 수 있다.

본 연구는 실태조사와 실증분석을 통해 사실관계가 확 인된 자료만을 근거로 조사 및 분석을 실시하였다. 그럼 에도 불구하고 본 연구는 다음과 같은 한계를 보이고 있다.

첫째, 기술이전 성과에 영향을 미치는 요인들을 모두 고려하는데 한계가 있었다. 전반적으로 기술성과에 영향 을 미치는 요인으로 대학의 특성, 산학협력단의 특성 기 술사업화 전담부서의 특성으로 나누어 살펴보고 있지만, 이 외에도 기술이전 성과에 영향을 미치는 요인이 존재 할 것이다. 따라서 향후에는 본 연구에서 다루지 못한 여 러 요인들을 탐색하고, 영향력의 정도를 분석하는 연구가 기대된다.

둘째, 대학에서의 기술이전 효율성 실증 분석을 위하 대학 및 기술이전에 관한 충분한 데이터 수집의 한계를 보이고 있다. DEA 효율성 분석의 특성상 효율성 값은 상 대적인 효율성 값을 산출하게 되는데, 수집된 데이터가 국내 소재 모든 대학을 포함하고 있지 않다.

셋째, 대학 TLO 육성 지원 사업은 2006년부터 2010년 까지 진행된 사업이다. 본 연구에서는 2007년도부터 2010년까지의 데이터를 사용하였으나, 사업이 완료되고 난 후인 2012년도에 설문조사한 데이터가 추가된다면, 대학 TLO 육성 지원 사업의 전체적인 평가도 가능할 것 이다.

이러한 한계에도 불구하고 본 연구에서 시도한 대학별 효율성 분석은 향후 국내 및 국외 효율성 비교 연구와 대 학의 기술이전 평가에 있어서 합리적인 측정지표를 제시 할 수 있을 것으로 기대된다.

\section{References}

[1] B. Kim, "2009 a white paper on Academic Industrial Cooperation", National Research Foundation of Korea, 2010.

[2] Y. Lee, "Strategies for the Successful Technology Transfer from Public Research Institutes in Korea", Journal of Technology Innovation, Vol. 16, No. 1, pp.141-163, 2008

[3] A. W. Charnes, W.W. Cooper, E. Rhodes, "Measuring the efficiency of decision making units, European Journal of Operational Research, Vol. 2, No. 6, pp. 429-444, 1978.

[4] J. Ahan, "Seller Recommendation for Comparison Shopping: Using DEA Model", Master's Thesis, Seoul National University, 2007.

[5] S. Kim, J. Park, J. Jo, "Comparative Study on Global Competitiveness of Healthcare Service Industry using DEA- Estimation with OECD Health Data 2007 -, Proc. of Joint Conference on Business Administration, pp. 1-17, 2008.

[6] Y. Jun, T. Choe, S. Kim, "Data envelopment analysis for evaluating the efficiency", Inha University Press, 2002.

[7] J. Ok, B. Kim, "Measuring the Performance of Technology Transfer Activities of the Public Research Institutes in Korea", Journal of Technology Innovation, 2009.

[8] J. B. Powers, "Commercializing academic research: Resource effects on performance of university technology transfer", The Journal of Higher Education, Vol. 74, No. 1, pp.26-50, 2003.

[9] J. Yang, "Key Performance model on the university-Institute R\&D cooperation Process", Master's Thesis, Seoul National University , 2005.

[10] C. Kim, S. Lee, "A Study on Relationships between Performance of University-Industry Cooperations and Competency Factors of University", Korea Technology Innovation Society, Vol. 10, No. 4, pp.629-653, 2007.

[11] K. Kim, H. Hyeon, "Effects of Institutional Environments and Strategic Resources of University TLOs on Technology Commercialization", Journal of business ventures, Vol. 9, No. 1, pp.87-109, 2006.

[12] D. S. Siegel, D. A. Waldman, A. N. Link, "Assessing the impact of organizational practices on the relative productivity of university technology transfer offices: an exploratory study", Research Policy, Vol.32, pp.27-48, 2003.

[13] C. Byun, "The Determinants of Performance of an Industry-Academy Cooperation: focused on university research capabilities", Master's Thesis, Sungkyunkwan University, 2004.

[14] R. A. Jensen, J. G. Thursby, M. C. Thursby, "Disclousure and licensing of univeristy inventions: The best we can do with the $\mathrm{s}^{* * \mathrm{t}}$ we get to work with", The International Journal of Industrial Organization, Vol. 21, 
pp.1271-1330, 2003.

[15] D. S. Siegel, D. A. Waldman, L. E. Atwater, A. N. Link, "Commercial knowledge transfer from universities to firms: Improving the effectiveness of university-industry collaboration", The Journal of High Technology Management Research, Vol. 14, pp.111-133, 2003.

\section{진 경 미(Gyungmi Jin)}

[준회원]

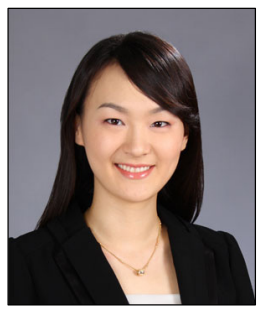

- 2003년 3월 2008년 8월 : 동 국대학교 산업시스템공학과 학 사

- 2011년 3월 현재 : 동국대학 교 산업시스템공학과 석사과정 (기술경영)

<관심분야>

기술사업화, 기술이전

\section{윤 병 운(Byungun Yoon)}

\section{[정회원]}

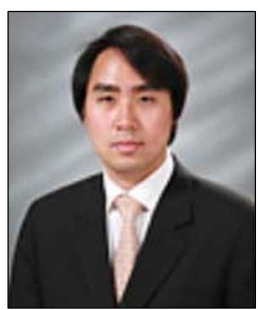

- 1998년 3월 2000년 2월 : 서 울대학교 산업공학과, 석사

- 2000년 3월 2005년 2월 : 서 울대학교 산업공학과, 박사(기술 경영)

- 2006년 5월 2007년 3월 : 캠 브리지 대학교, Visiting Scholar

- 2007년 3월 현재 : 동국대학 교, 산업시스템공학과, 조교수

<관심분야>

특허분석, 기술로드맵, 기술 인텔리전스, 기술예측 